\title{
Detection of antibacterial activities of Miswak, Kalonji and Aloe vera against oral pathogens \& anti-proliferative activity against cancer cell line
}

Sameen Amjed ${ }^{1,2^{*}}$, Kashaf Junaid ${ }^{2}$, Junaid Jafar², Tuaha Amjad ${ }^{3}$, Waqas Maqsood² ${ }^{2}$ Nadia Mukhtar ${ }^{2}$, Kanza Tariq ${ }^{1}$, Musarrat Sharif ${ }^{1}$, Sana Javaid Awan ${ }^{1}$ and Farheen Ansari ${ }^{1}$

\begin{abstract}
Background: Emerging drug resistance and hindrance of treatment is provoking scientists to search new, less expensive medicinally active compounds. Dental diseases caused by oral pathogens are very frequent chronic infections around the world. The medical potentials of a lot of Pakistani local herbs and herbal combinations is relatively unknown, hence attempted to explore. A study was designed to investigate potential role of local medicinal herbs for example Miswak, Kalonji \& Aloe vera as antimicrobial, antioxidant and anti-proliferative agents against oral pathogens and cancer cell line.
\end{abstract}

Methods: Medicinal extracts were prepared in solvents of different polarities. Their antimicrobial activity was determined alone and in combination against oral pathogens. Antioxidant activity was evaluated through Catalase and Superoxide dismutase assay and anti-proliferative activity was evaluated through 3-(4, 5-Dimethylthiazol-2-YI)-2,5-Diphenyltetrazolium Bromide) assay.

Results: Plant extracts alone and in combinations were found significantly effective as antimicrobial agent against standard ATCC strains of C. albicans and S. aureus ( $\left.P^{<} 0.001\right)$. Especially Miwak extract was found highly significant against fungus. Extracts of Kalonji were found significant in inhibiting growth of HeLa cell lines. Miswak and Kalonji showed significant levels of antioxidant activity.

Conclusion: Medicinal herbs Miswak and Kalonji have potential to be used for therapeutic purposes. Results suggested that herbal medicinal composition can be prepared using these extracts after applying scientific standardization methods.

Keywords: Herbal medicine, Antimicrobial, Anti cancer, Antioxidant

\section{Background}

Since thousands of years herbal products have been the basis for medical treatments and are recognized as a form of alternative medicine. Modern medicine also employs use of many herbal products for therapeutic purposes [1]. The emerging trends of various antimicrobial compounds is alarming; and from last few years

\footnotetext{
* Correspondence: amjedsameen@gmail.com

'Institute of Molecular Biology and Biotechnology (IMBB), The University of Lahore, Lahore, Pakistan

2Department of University Institute of Medical Laboratory Technology, The University of Lahore, $1 \mathrm{~km}$ Defence Road off Raiwind road Lahore, Lahore, Pakistan

Full list of author information is available at the end of the article
}

researchers are in attempt to search new alternative medicines for treatment of different infectious diseases [2]. Herbal medicines are specially recommended for those patients who cannot use chemical products due to their adverse and biochemical contraindications $[3,4]$.

World Health Organization (WHO) estimates that $80 \%$ of the population in developing countries employs the usage of herbal medicine to treat aspects of primary health care. These medicines also serve as precursor for 20 to $25 \%$ of modern medicine as these herbal medicines are considered to be economical, safer and less toxic $[5,6]$. 
Three medically acclaimed plants were included in this study: Miswak (Salvadora persica) a medicinal herb which is commonly available and very cost effective. It is reported to have antibacterial, antifungal, antioxidant and anticancer properties $[7,8]$. Aloe vera is a medicinal herb whose mucilaginous gel is traditionally used to treat different diseases. It is very popular among scientists for its medicinal properties [9]. Of the overall weight of Aloe vera $2 \%$ consist of the active compounds which include methylchromones, flavonoids, aloesin, aloe-emodin, sterols, amino acids, aloemannan, aloin, acemannan, aloeride, naftoquinones, saponin and vitamins. It is considered to be antibacterial, anti-inflammatory and antioxidant $[10,11]$. Another important medicinal herb Nigella sativa (Kalonji) used in this study is reported to possess antimicrobial, anti-inflammatory, antiulcer, anticancer, immune stimulating and antioxidant activity [12-14]. Phytochemical analysis of Nigella seeds revealed that it contains a variety of volatile oil and fixed oil and other components including Nigellin, Carvone, Melanthin, Carvene, Cymene and Thymoquinone [14]. A lot of medicinal plants elaborate variety of compounds majority of which have extremely important properties particularly antimicrobial activity and some herbs also possess anticancer activity. Many medicinal herbs are reported to cure different acute and chronic infections including dental infections. Dzoyem in 2016 also have reported antimicrobial activities and anti-cancer activities of fourteen herb against common pathogens [15].

Herbs to herb combinations have been traditionally used in different regions around the word form thousands of years, however scientific evidence based data is still lacking. Traditionally co-administration of herb is believed to influence the overall effect of herb, either complementary or antagonistic [16]. Herbs are believed to contain several potential sources of potent biological compounds. Using herb in combination with others herb or along with antibiotics can produce additional benefits and also reduce the toxicity of herb. Generally herbal combinations are used due to number of reasons as it is believed that their use in combination may give rise to synergistic or additive effect which ultimately helps to overcome drug resistance and increase the spectrum of activity. It may reduce the required dose of administration of any drug and reduce the overall cost along with the side effects [17]. A similar concept in modern medicine is the use of "cocktail" in antiretroviral therapy (HAART) [16]. However less data is present to use these herbs in combinations against oral pathogens. So this study was aimed to ascertain following objectives; to determine antimicrobial activity of these herbs (Kalonji, Miswak and Aloe Vera) against oral pathogens, to evaluate anti-proliferative activity against $\mathrm{HeLa}$ cell line and also antioxidative ability.

\section{Methods}

\section{Preparation of plant extracts}

Samples of under study medicinal plants Miswak stem, Kalonji seed and Aloe vera leaves were collected from local market Lahore after inspecting the organoleptic properties of herbs and final identification was done by herbalist [18]. The preserved herb samples have been submitted with voucher number UOL/PDH627A-C in Herbarium Department of Pharmacy, The University of Lahore. Dried plant samples of Kalonji and Miswak were crushed to fine particle size using motor pestle. For collecting gel from Aloe Vera leaves were freshly cut and washed with distilled water, cuticle was carefully removed and jell was collected [10]. Cold maceration method of extraction was used for the preparation of plant extract in which $200 \mathrm{~g}$ crushed plant material was placed in a screw cap container with $600 \mathrm{ml}$ of solvent. Solvents of different polarities were used in this study including petroleum ether, water and ethanol. The herbs macerated in solvents petroleum ether and ethanol was kept in shaker set at room temperature for a period of 7 days. The plant materials macerated in water were kept at room temperature at shaker for 24 hours. Due to the climate conditions it was not possible to macerate water part for 7 days. The Miswak sample macerated in petroleum ether was macerated for 21 days because after 7 days very negligible amount of extract was obtained. All the preparations were filtered with Whatman's filter paper no1 $[10,19]$. In all nine filtrates of Petroleum ether Miswak (PM), Ethanol Miswak (EK), Water Miswak (WK), Petroleum ether Kalonji (PK), Ethanol Kalonji (EK), Water Kalonji (WK), Petroleum ether Aloe vera (PA), Ethanol Aloe vera (EA) and Water Aloe Vera (WA) were obtained and shade dried at room temperature. Plant extracts were dissolved in DMSO to obtain 500, 1000 and $2000 \mu \mathrm{g} /$ disk concentration and subjected to vortex to obtain a homogenized suspension.

\section{Plant extract in combinations}

Eighteen different combinations were prepared (Fig. 1a and b). All combinations were applied at $2000 \mu \mathrm{g} /$ disc concentration of plant extract. These plant extract in combinations were tested against organisms in triplicate. DMSO was used as negative control, Nystatin $100 \mathrm{IU} /$ disc and Ciprofloxacin $5 \mu \mathrm{g} / \mathrm{disc}$ was used as positive control against Candida albicans and Staphylococcus aureus respectively.

\section{Detection of antimicrobial activity}

Test organism Staphylococcus aureus (ATCC-29213) and Candida albicans (ATCC-14053) were further confirmed by their morphological, physiological and biochemical characteristics. The strains were stored at $-80{ }^{\circ} \mathrm{C}$ in the form of glycerol stocks and were sub cultured at $37^{\circ} \mathrm{C}$ for 


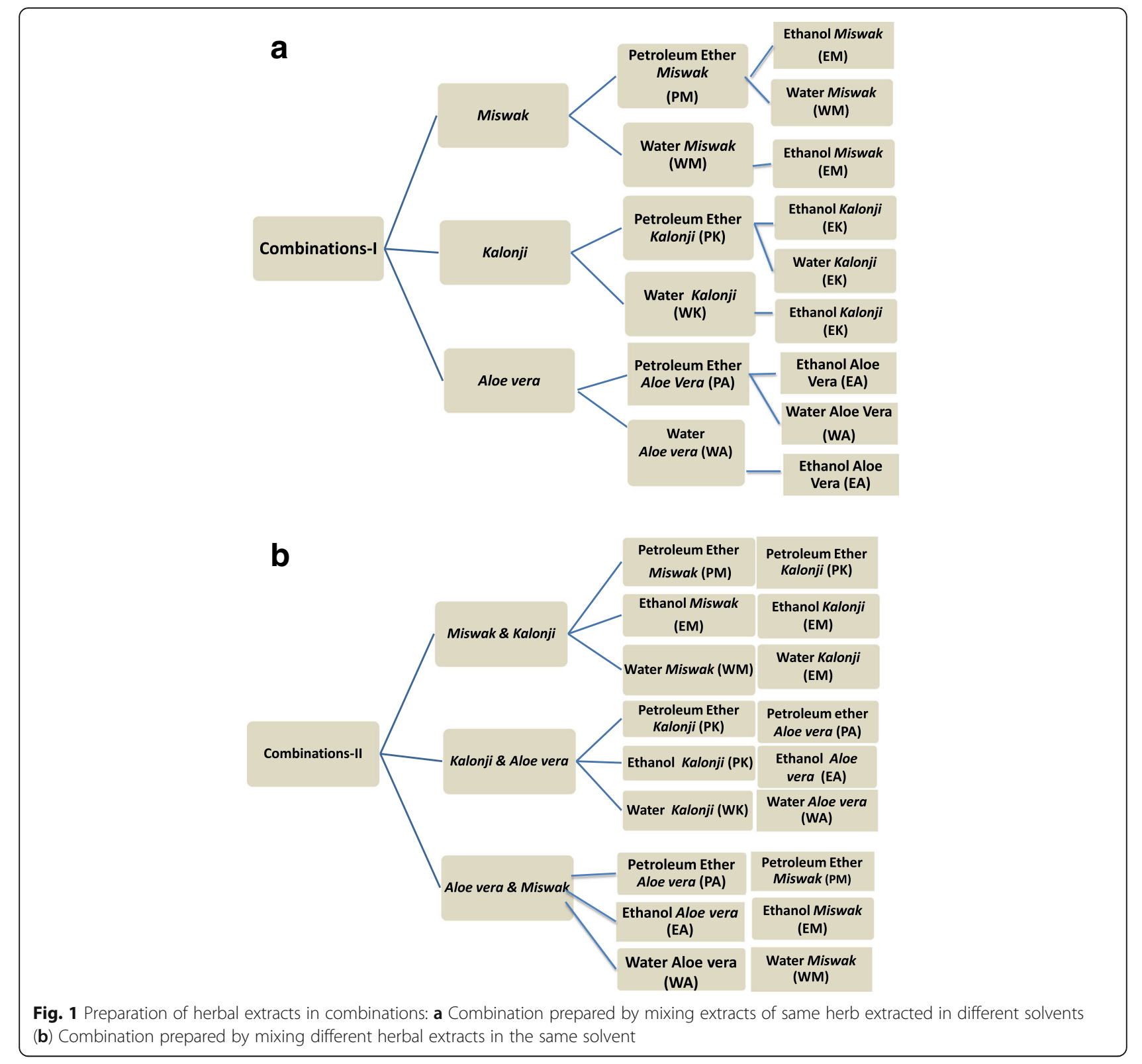

24 hour; first on nutrient agar and later nutrient broth, before use in susceptibility test. Growth was matched with 0.5 McFarland solutions to prepare the inoculums. Plates of Muller-Hinton agar for bacteria and Sabouraud dextrose agar for fungus were prepared. Bacterial suspension (200 $\mu \mathrm{l}$ volume) was poured and allowed to adsorb over the agar surface. Sterile whatman's filter paper no1 discs (6 $\mathrm{mm}$ in diameter) were freshly impregnated with required concentration of extract $(500,1000 \& 2000 \mu \mathrm{g} / \mathrm{disc})$. However extracts in combination were tested for only one concentration $(2000 \mu \mathrm{g} /$ disc). Ciprofloxacin $(5 \mu \mathrm{g})$ and Nystatin (100 IU) were used as positive control for $S$. aureus and $C$. albicans respectively while DMSO was used as negative control. These culture plates were incubated at $37^{\circ} \mathrm{C}$ for 24 hours. All extracts were run in triplicates and results recorded as zone of inhibition in $\mathrm{mm}$ [10]. Minimum inhibitory concentration was determined for those extracts which were producing significant zone of inhibition.

\section{Treatment of HeLa cell line with plant extracts}

Stock solution of plant extracts were prepared by dissolving the extracts in DMSO at a concentration of $20 \mathrm{mg} / \mathrm{ml}$. Sterile working solutions of extracts named pre-treatment medium were prepared by the addition of DMEM-HG (Dulbecco's Modified Eagle's-High Glucose medium) and the final concentration was $1 \mathrm{mg} / \mathrm{ml}$ [20]. Different group of treatment were named as: a) $\mathrm{HeLa}$ 
cells treated with Miswak extracts in ethanol (He-T-M-E), water (He-T-M-W) and petroleum ether (He-T-M-PE), b) $\mathrm{HeLa}$ cells treated with Kalonji extracts in ethanol (He-T$\mathrm{K}-\mathrm{E})$, water (He-T-K-W) and petroleum ether (He-T-K-PE), c) HeLa cells treated with Aloe vera extracts in ethanol (He-T-A-E), water (He-T-A-W) and petroleum ether (He-T-A-PE). The treatment of cell line with plant extracts was continued for 24 hours and after this anti-proliferation and antioxidant activities of medicinal extracts were determined.

\section{Anti-proliferation activity of plant extracts}

To determine anti proliferative activity of treated HeLa cells MTT (3-(4, 5-Dimethylthiazol-2-Yl)-2,5Diphenyltetrazolium Bromide) assay was performed. Treatment medium was removed from micro titer plate and $100 \mu \mathrm{l}$ of fresh medium was added on the cells. Then $25 \mu \mathrm{l}$ of MTT solution ( $5 \mathrm{mg} / \mathrm{ml}$ ) was added to respective wells and incubated at $37{ }^{\circ} \mathrm{C}$ for 2 hours after which purple colored water insoluble formazan crystals appear at the bottom of wells micro titer plate, then $100 \mu \mathrm{l}$ of $10 \%$ Sodium dodecyl sulphate was added to solubilize the formazan crystals for 4 hours. Absorbance (A) was taken at $570 \mathrm{~nm}$. All experiments were performed in triplicate.

\section{Estimation of antioxidant levels}

For the estimation of antioxidant level Superoxide dismutase SOD) and Catalase (CAT) activities were determined in the pretreatment and post treatment medium [21].

\section{Superoxide dismutase assay (SOD)}

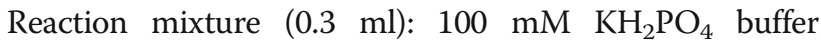
(pH 7.8), 0.1 mM EDTA, 13mMMethionine, $2.25 \mathrm{mM}$ NBT (Nitroblue tetrazolium), $60 \mu \mathrm{M}$ Riboflavin and plant extracts was prepared. Absorbance was taken at $560 \mathrm{~nm}$ after 10 minute of incubation at room temperature.

\section{Catalase assay (CAT)}

To determine Catalase activity reaction mixture $(0.3 \mathrm{ml})$ : $1 \mathrm{M} \mathrm{KH}_{2} \mathrm{PO}_{4}, 100 \mathrm{mM} \mathrm{H} \mathrm{O}_{2}$ and plant extract was added in 96 well plate. Absorbance was taken at $240 \mathrm{~nm}$ within one min at room temperature.

\section{Statistical analysis}

The results obtained through antimicrobial, antiproliferative and antioxidant assays were statistically analyzed by SPSS version 20. Descriptive analysis was performed by using Anova test, mean differences of zone of inhibition, anti-proliferative and antioxidant activity verses control was reported with standard error. Figures were drawn by using Graph-pad Prism version 5. Values were considered significant at $P \leq 0.05$.

\section{Results}

Percentage yield of medicinal plant extracts

In this study total nine medicinal plant extracts were prepared in solvents of different polarities. The percentage yield of extract obtained from under study crude plant material is given in Table 1.

\section{Antimicrobial activity of medicinal plant extracts}

The results of this study showed that under studied plant extracts in all solvents were ineffective against Staphylococcus aureus at all concentrations used in this study. Similar findings were observed for Candida albicans except Miswak extract in petroleum ether which showed significant results at all three concentrations $(500,1000 \& 2000 \mu \mathrm{g} /$ disk) and produced zone of inhibition, $73 \pm 0.5 \mathrm{~mm}, 80.5 \pm 1.5 \mathrm{~mm}$ and $89.6 \mathrm{~mm} \pm 0.5 \mathrm{~mm}$. Minimum inhibitory concentration (MIC) of this extract was $18.3 \mathrm{~mm}$ at concentration $31.25 \mu \mathrm{g} /$ disk (Fig 2).

\section{Antimicrobial activity of extracts in combinations}

When these plants extracts were used in combination they were found very effective as antimicrobial agent against both test organisms and significant inhibitory zones were obtained $(P<0.001)$. The minimum and maximum mean zone size produced by extract combinations against Candida albicans were $7 \mathrm{~mm}-66 \mathrm{~mm}$ and $7 \mathrm{~mm}-52 \mathrm{~mm}$ against Staphylococcus aureus. Of all combinations applied on Candida albicans PM in combination with PK gave the maximum zone of inhibition of $66.5 \pm 0.7 \mathrm{~mm}$ while EM in addition with WM and PK with PA produced no zone of inhibition. Moreover, three other extract combinations $\mathrm{PM}+\mathrm{EM}, \mathrm{PM}+\mathrm{WM}$ and $\mathrm{PA}+\mathrm{PM}$ produced significant zone of inhibition of $61 \pm 0.7 \mathrm{~mm}, 55 \pm 0.7 \mathrm{~mm}$ and $65.5 \pm 0.7 \mathrm{~mm}$ respectively.

In contrast when extract combinations were tested against Staphylococcus aureus PM in addition with EM

Table 1 Percentage yield of extract

\begin{tabular}{|c|c|c|c|c|}
\hline Botanical name & Local name & $\begin{array}{l}\text { Plant part } \\
\text { used }\end{array}$ & Solvent & $\begin{array}{l}\text { Percentage } \\
\text { yield }\end{array}$ \\
\hline \multirow[t]{3}{*}{ Salvadora presica } & Peelu Miswak & Stem & Water & $2.75 \%$ \\
\hline & & & $\begin{array}{l}\text { Petroleum } \\
\text { ether }\end{array}$ & $0.35 \%$ \\
\hline & & & Ethanol & $1.75 \%$ \\
\hline \multirow[t]{3}{*}{ Nigella sativa } & Kalonji & Seeds & Water & $0.2 \%$ \\
\hline & & & $\begin{array}{l}\text { Petroleum } \\
\text { ether }\end{array}$ & $0.25 \%$ \\
\hline & & & Ethanol & $0.7 \%$ \\
\hline \multirow[t]{3}{*}{ Aloe vera } & Kanwar gandal & Leaves & Water & $2.5 \%$ \\
\hline & & & $\begin{array}{l}\text { Petroleum } \\
\text { ether }\end{array}$ & $7.5 \%$ \\
\hline & & & Ethanol & $8.75 \%$ \\
\hline
\end{tabular}




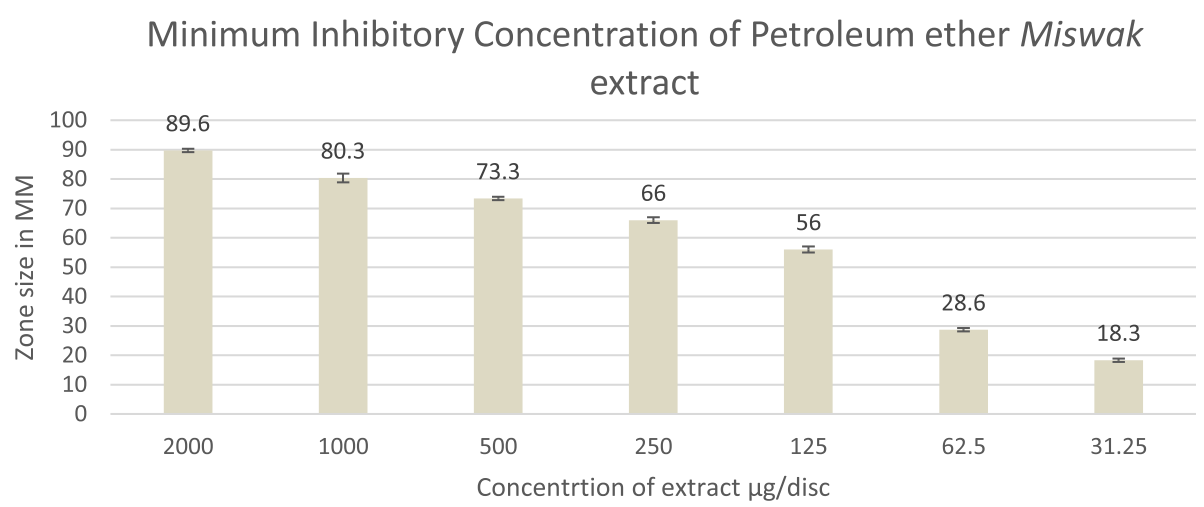

Fig. 2 Minimum inhibitory concentration of Miswak extracted in petroleum ether against C. albicans

and PA in addition with PM give the maximum mean zone of $52.5 \mathrm{~mm}$. Likewise extract combination PM with $\mathrm{PK}$ and PM with WM also produced significant inhibitory zone of $51 \mathrm{~mm}$ and $46 \pm 0.00 \mathrm{~mm}$ respectively (Fig. 3). Table 2 describes the zone of inhibition produced by all extract combinations against both test organisms. Zone of inhibition produced by Miswak extract prepared in petroleum ether (PM) alone and in combination with ethanol (EM) against test organisms is presented in Fig. 4a and b.

\section{Anti-proliferative and antioxidant activity of medicinal plant extracts}

The results of MTT assay indicate that significantly low proliferation rate was observed in the presence of two medicinal plant extracts PK (Petroleum ether Kalonji) and EK (Ethanol Kalonji) $(P<0.05)$, which shows the significant difference in the proliferation rate in control cells versus the cells exposed to herbal extracts. The other herbal extracts were not found anti-proliferative against HeLa cell line (Fig. 5).
The results of Catalase and Superoxide dismutase antioxidant assays shows that four herbal extracts EK (Ethanol Kalonji), PK (Petroleum ether Kalonji), WK (Water Kalonji) and PM (Petroleum ether Miswak) showed significant level antioxidant activity $(P<0.001)$ indicates significance of difference between the pretreatment and post-treatment antioxidant ability of these herbal extracts as presented in Table 3. All other extracts including EM, WM, EA, PA and WA showed no significant difference between the Catalase and SOD levels of pre-treatment and post-treatment samples of herbal extracts (Fig. 6a and b).

\section{Discussion}

The results of this study indicate that medicinal herbs Miswak, Kalonji \& Aloe vera contain significant level of antimicrobial, antioxidant and anti-proliferative agents in them and hence needed to be further explored. Production of synthetic drugs effectively improves the health care facilities around the world. In developing

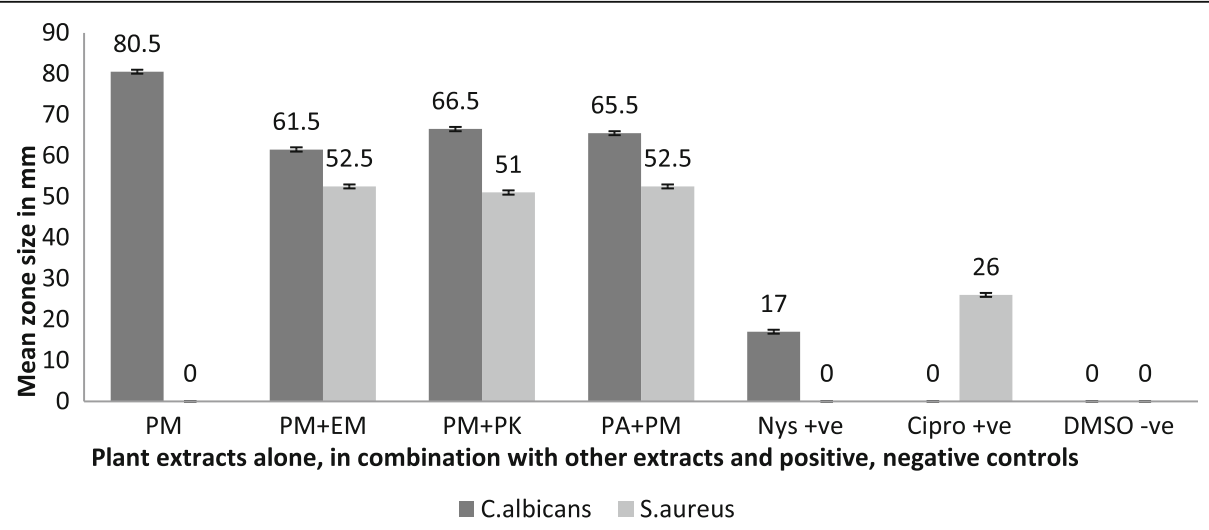

Fig. 3 Activity of Miswak alone and in combination with Aloe vera and Kalonji against S. aureus and C. albicans. Petroleum ether Miswak + Ethanol Miswak (PM+EM), Petroleum ether Miswak + Water Miswak (PM+EM), Petroleum ether Miswak + Petroleum ether Kalonji (PM+PK), Petroleum ether Aloe vera + Petroleum ether Miswak (PA+PM), Nystatin $100 \mathrm{IU} /$ disc and Ciprofloxacin $5 \mathrm{\mu g} /$ disc as positive control, and DMSO as negative control 
Table 2 Mean zone of inhibition produced by herbal extract when used in combinations against S. aureus and C. albicans

\begin{tabular}{|c|c|c|c|}
\hline Combination & S. aureus & C. albicans & $P$ value \\
\hline $\mathrm{PM}+\mathrm{EM}$ & $52 \mathrm{~mm} \pm 0.7$ & $61.5 \mathrm{~mm} \pm 0.7$ & $\mathrm{~S}^{*}$ \\
\hline $\mathrm{PM}+\mathrm{WM}$ & $46 \mathrm{~mm} \pm 0$ & $55 \mathrm{~mm} \pm 0.7$ & $\mathrm{~S}^{*}$ \\
\hline$E M+W M$ & $0 \mathrm{~m}$ & $0 \mathrm{~mm}$ & NS \\
\hline $\mathrm{PK}+\mathrm{EK}$ & $9 \mathrm{~mm} \pm 0$ & $8 \mathrm{~mm} \pm 0$ & NS \\
\hline WK+PK & $8 \mathrm{~mm} \pm 0.7$ & $10 \mathrm{~mm} \pm 0.7$ & NS \\
\hline$E K+W K$ & $8 \mathrm{~mm} \pm 0$ & $7 \mathrm{~mm} \pm 0$ & NS \\
\hline $\mathrm{PA}+\mathrm{EA}$ & $7 \mathrm{~mm} \pm 0$ & $11 \mathrm{~mm} \pm 0.7$ & NS \\
\hline WA+PA & $0 \mathrm{~mm}$ & $8 \mathrm{~mm} \pm 0$ & NS \\
\hline$E A+W A$ & $0 \mathrm{~mm}$ & $7 \mathrm{~mm} \pm 0$ & NS \\
\hline $\mathrm{PM}+\mathrm{PK}$ & $50 \mathrm{~mm} \pm 1.4$ & $66.5 \mathrm{~mm} \pm 0.7$ & $\mathrm{~S}^{*}$ \\
\hline $\mathrm{PK}+\mathrm{PA}$ & $10 \mathrm{~mm} \pm 0.7$ & $0 \mathrm{~mm}$ & NS \\
\hline $\mathrm{PA}+\mathrm{PM}$ & $52 \mathrm{~mm} \pm 0.7$ & $65.5 \mathrm{~mm} \pm 0.7$ & $\mathrm{~S}^{*}$ \\
\hline $\mathrm{EM}+\mathrm{EK}$ & $0 \mathrm{~mm}$ & $9 \mathrm{~mm} \pm 0$ & NS \\
\hline $\mathrm{EK}+\mathrm{EA}$ & $11 \mathrm{~mm} \pm 0.7$ & $12 \mathrm{~mm} \pm 0$ & NS \\
\hline $\mathrm{EA}+\mathrm{EM}$ & $7 \mathrm{~mm} \pm 0$ & $10 \mathrm{~mm} \pm 0$ & NS \\
\hline WM+WK & $0 \mathrm{~mm}$ & $10 \mathrm{~mm} \pm 0.7$ & NS \\
\hline WK+WA & $0 \mathrm{~mm}$ & $11.5 \mathrm{~mm} \pm 0.7$ & NS \\
\hline WA+WM & $0 \mathrm{~mm}$ & $9.5 \mathrm{~mm} \pm 0.7$ & NS \\
\hline $\begin{array}{l}\text { DMSO Negative } \\
\text { control }\end{array}$ & $0 \mathrm{~mm}$ & $0 \mathrm{~mm}$ & - \\
\hline $\begin{array}{l}\text { Ciprofloxacin } \\
\text { Positive control }\end{array}$ & $26 \mathrm{~mm} \pm 0$ & NA & - \\
\hline $\begin{array}{l}\text { Nystatin Positive } \\
\text { Control }\end{array}$ & NA & $17 \mathrm{~mm} \pm 0$ & - \\
\hline
\end{tabular}

Petroleum ether Miswak + Ethanol Miswak(PM+EM), Petroleum ether Miswak + Water Miswak (PM+EM), Ethanol Miswak + Water Miswak (EM+WM), Petroleum ether Kalonji + Ethanol Kalonji (PK+EK), Water Kalonji+ Petroleum ether Kalonji (WK+PK), Ethanol Kalonji + Water Kalonji (EK+WK), Petroleum ether Aloe vera + Ethanol Aloe vera (PA+EA), Water Aloe vera + Petroleum ether Aloe vera (WA+PA), Ethanol Aloe vera + Water Aloe vera (EA+WA), Petroleum ether Miswak +

Petroleum ether Kalonji (PM+PK), Petroleum ether Kalonji + Petroleum ether Aloe vera (PK+PA), Petroleum ether Aloe vera + Petroleum ether Miswak (PA+PM), Ethanol Miswak + Ethanol Kalonji (EM+EK), Ethanol Kalonji + Ethanol Aloe vera $(\mathrm{EK}+\mathrm{EA})$, Ethanol Aloe vera + Ethanol Miswak (EA+EM), Water Miswak + Water Kalonji (WM+WK), Water Kalonji + Water Aloe vera (WK+WA), Water Aloe vera + Water Miswak (WA+WM). NA: not applicable, S: Significant and NS: Non-significant $\mathrm{S}^{*}:$ Significant

countries still local herbal products are common to treat a lot of diseased conditions due to their cost effectiveness and less side effects [22]. Fabricant \& Farnsworth in 2001 reported active compounds obtained from herbal products have $80 \%$ correlation between their traditional use and use in modern therapeutics $[16,23]$. Rath S and Padhy RN in 2015 stated that therapeutic plants have immense potential to be used in integrative and synergistic drug development [24].

Test organisms in this study Staphylococcus aureus and Candida albicans are the most common cause of oral infections across the world $[25,26]$. Our findings of herbal extracts affectivity against oral pathogens are in consistence with previous reports [7, 8, 27]. Al-Obaida
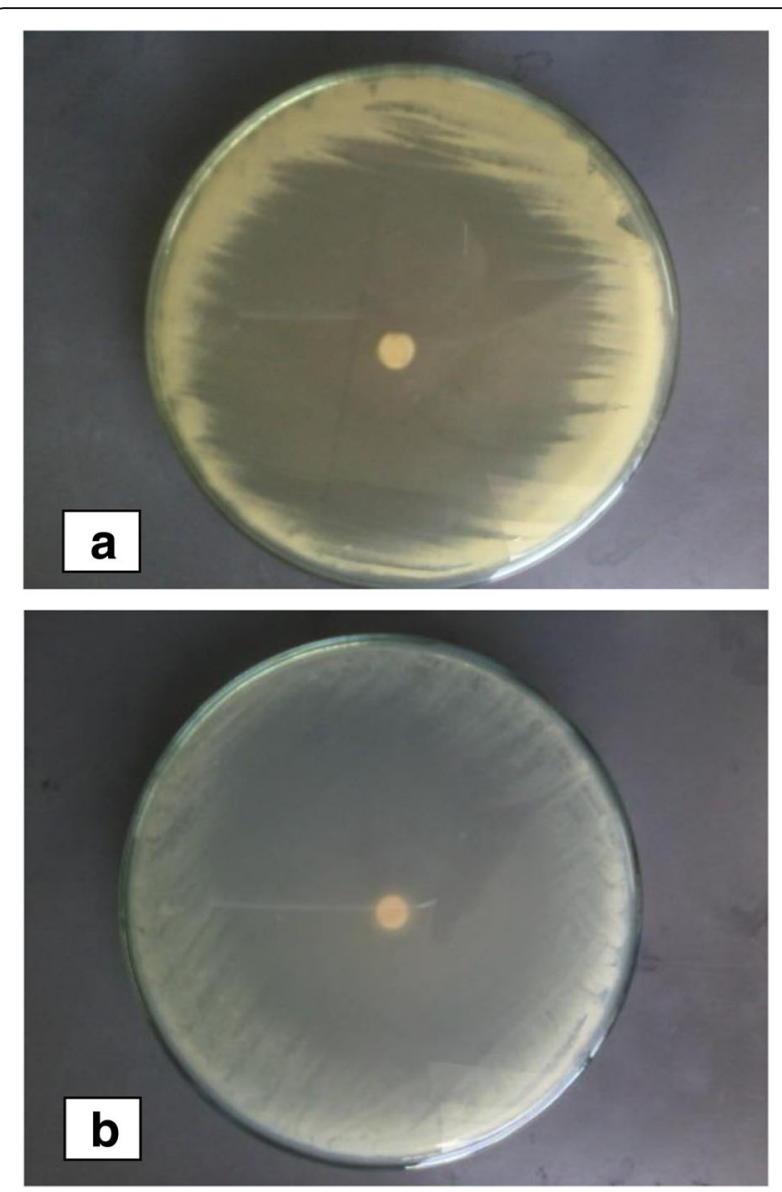

Fig. 4 Zone of inhibition produced by miswak extract in Petroleum ether alone and in combination with ethanol against both test organisms. a PM extract against c. albicans, b PM+EM extract combination against S. aureus

and coauthors declared miswak as an effective oral hygienic tool and found it helpful against different organisms causing oral cavity infections [28, 29]. A study conducted by Heshama A.E 2016 stated that the beneficial effects of miswak on oral health are due to presence of different important minerals and compounds. The combination of Benzyllisothiocyanate, salvadorine, fluoride, tannins, vitamin C, Silica, chloride and essential oils contribute to the value of miswak [30].

The results of this study are comparable with the previous studies as the prepared (PM) Miswak extract produced significant zone of inhibition against Candida albicans but contrary to this aqueous and ethanol extracts were found ineffective when applied on both test organisms. Another study showed that aqueous and ethanolic extracts of Miswak produced significant zone of inhibition against Staphylococcus aureus and Candida albicans [27]. Salehi et al. also showed that Miswak extracts used in form of mouthwash were effective against oral pathogens [29]. Another study reported reduction 


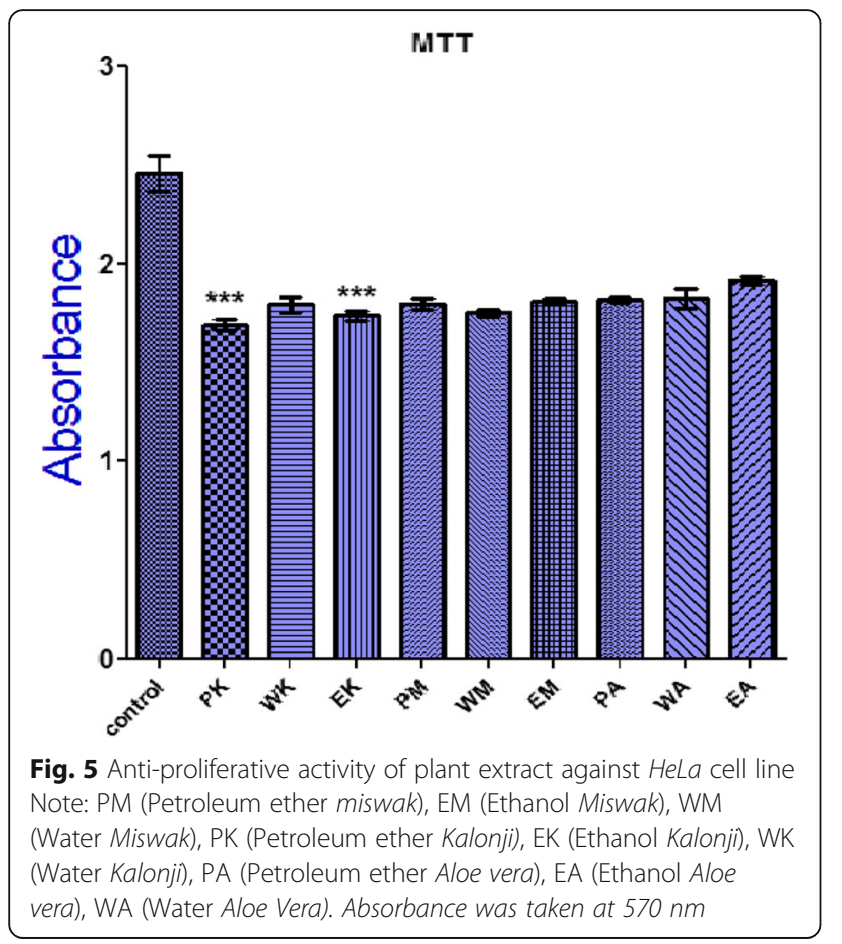

w? >in number of organism by the use of Miswak extracts as mouth wash [27]. Omer et al. stated that Miswak extracts when preparedin solventschloroform, ethylacetateandethanolitproduced no zone of inhibition against Candida albicans and Staphylococcus aureus but its aqueous extract was effective [31]. In contrast to Al-Obaida et al. reported herbal ethanol extracts were effectiveagainstS. aureus and C. albicans.In2013Baftietal. reportedMiswakextractscontaingoodantifungal properties [3]. Finding of our studyalso suggest Miswak as an antioxidantagent itcontain antioxidantcompounds for example peroxidase, catalase and polyphenol oxidase representing it as a good chewing stick[7].

These inconsistent findings of miswak extract are might be due to the difference in the environmental, climate, and harvesting conditions of herbs. The results of our study show some difference as compared to the published data. But there are inconsistent reports regarding herbal activities. These variation in the activity of herb results are comparable with other studies including Teka et al. [32], Darout et al. [22], Bakathir and Abbas [33], Togan et al. [18], Khan et al. [14]. Findings of these authors suggest that variation in results of herbs when applied against organism can come due to many reasons for example geographical location, harvesting conditions,

Table 3 Pre and post-treatment of catalase and superoxide dismutase activity of herbal extracts

\begin{tabular}{|c|c|c|c|c|}
\hline Assay & Extract & Pre-treatment & Post-treatment & $P$ value \\
\hline \multirow[t]{10}{*}{ Catalase (CAT) } & Control & 0.19 & 0.43 & $S^{*}$ \\
\hline & EK & 1.3 & 0.14 & $\mathrm{~S}^{*}$ \\
\hline & PK & 1.5 & 0.15 & $S^{*}$ \\
\hline & WK & 1.1 & 0.22 & $S^{*}$ \\
\hline & EM & 0.54 & 0.18 & NS \\
\hline & PM & 0.96 & 0.42 & NS \\
\hline & WM & 0.37 & 0.17 & NS \\
\hline & EA & 0.62 & 0.26 & $\mathrm{~S}^{*}$ \\
\hline & PA & 0.41 & 0.18 & $S^{*}$ \\
\hline & WA & 0.32 & 0.16 & $S^{*}$ \\
\hline \multirow[t]{10}{*}{ Superoxide dismutase (SOD) } & Control & 0.19 & 0.28 & $\mathrm{~S}^{*}$ \\
\hline & EK & 1.9 & 0.68 & NS \\
\hline & PK & 2.7 & 0.69 & NS \\
\hline & WK & 1.6 & 0.91 & NS \\
\hline & EM & 1.1 & 0.91 & $\mathrm{~S}^{*}$ \\
\hline & PM & 2.6 & 1.6 & NS \\
\hline & WM & 0.96 & 0.73 & $\mathrm{~S}^{*}$ \\
\hline & EA & 1.2 & 1.1 & $\mathrm{~S}^{*}$ \\
\hline & PA & 1.2 & 0.90 & $\mathrm{~S}^{*}$ \\
\hline & WA & 0.93 & 0.91 & $S^{*}$ \\
\hline
\end{tabular}

Ethanol Kalonji (EK), Petroleum ether Kalonji (PK), Water Kalonji (WK), Ethanol Miswak (EM), Petroleum ether Miswak (PM), Water Miswak (WM), Ethanol Aloe vera (EA), Petroleum ether Aloe vera (PA) and Water Aloe vera (WA). Values represented as absorbance at $240 \mathrm{~nm}$ for Catalase assay and at $560 \mathrm{~nm}$ for Superoxide dismutase respectively. "NS" non-significant and "S" significant. Values were considered significant at $P \leq 0.05$.

$\mathrm{S}^{*}$ :Significant 


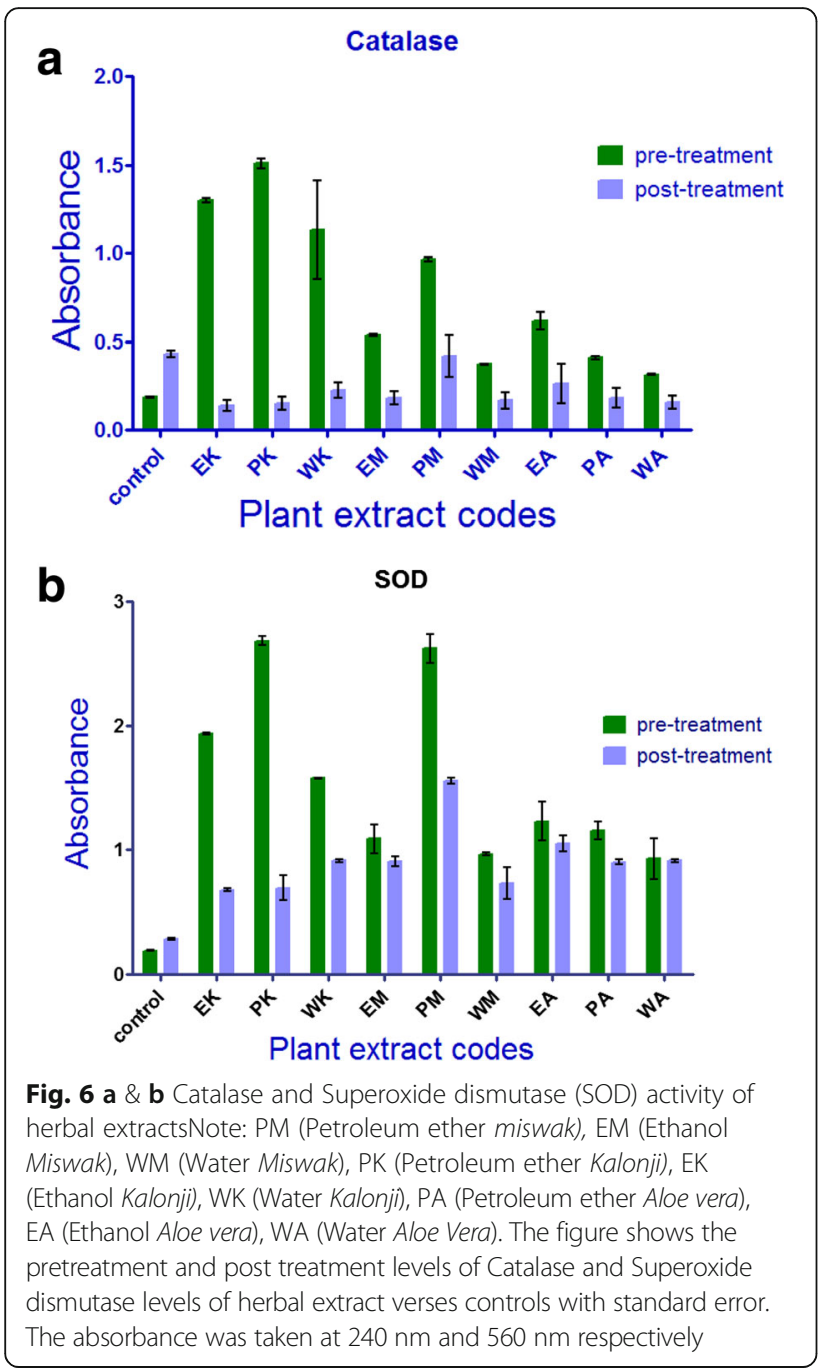

chemical constituents and use of different techniques of extraction. Activity of the herb also varies if the organism is isolated from clinical samples or standard strains $[18,22,32-34]$.

Aloe vera being a phytotherapic agent also act as inhibitory factor for the growth of wide range of oral microorganisms and is reported to significantly reduce intensity of gingivitis and plaque formation [35, 36]. However, in this study Aloe vera extracts did not exhibit antimicrobial activity in consistent with previous studies where it's aqueous and methanol extracts were found effective against Candida albicans but were ineffective against Staphylococcys aureus [37].

Kalonji also called miracle herb due to its medicinal properties. It is a commonly grown herb all over the world. In herbal medicine its seeds are commonly used to treat many diseases $[14,38]$. Many studies reported it's antioxidant, antibacterial, antifungal, anti-plaque and antiproliferation activities [14]. The results of our study also showed similar findings as extracts prepared from Kalonji showed significant antioxidant and anti-proliferative abilities especially when extracted in ethanol and petroleum ether but not antimicrobial activity. A study conducted by Khan et al. 2013 in Pakistan also show comparable result to our finding where Nigella extracted in methanol was found ineffective when applied against $S$. aureus. Studies also suggested that biologically active medicinal plants can show inhibitory activity against some organism but can be ineffective against others [34].

Our finding that extracts in combinations produce significant antimicrobial activity, when applied on both test organisms $(P<0.001)$ is striking. In some extracts when they were tested as alone extracts were not active against Staphylococcus aureus while when tested in combinations with other extracts significant zone of inhibitions were produced this may be attributed by the synergistic and antagonistic effect produced by constituents of herbal extract $[39,40]$.

The study conducted by Bag et al. in 2015 also enforce that when two herbs are given in combination the biological effects of herbal combination is enhanced and show synergistic effect [17]. This synergistic effects are due to the interrelationships of herbal ingredients where synergy can be broadly classified into two main categories based on the mode of actions including pharmacodynamic (when two or more constituents work on same biological targets and result in improved therapeutic outcomes) and pharmacokinetic (two or more constituents interactions between their metabolic processes, absorption, distribution and elimination) [41].

This study was designed with the hypothesis that medical herbs contain potent antitumor and anti cancerous agent. We examined the effect of Kalonji, Miswak and Aloe vera extracts in petroleum ether, ethanol and water at a concentration of $1 \mathrm{mg} / \mathrm{ml}$. Findings suggest only Kalonji extracted in petroleum ether and in ethanol have anti-proliferation activity with a statistical border line significant $p$ value. These results are in agreement with previous studies already reported anti proliferative and antioxidant activity of herbs [20, 27, 29].

As the effectiveness of these herbs in combination have not been previously explore that provides this study more strength. However, there are few limitations of this study; due to limited availability of extract it was not possible to test herbal combinations at different concentrations and it was also not possible to make further herbal combinations so only 18 different combinations of extracts were used. This small volume of our extracts also made it impossible to test anti-proliferative activity on other cell lines this leads to uncertainty in these results. However it is recommended to further check the activities of these herbs on other cell lines.

This study suggests medicinal herbs particularly Miswak and Kalonji have potential to be used for 
therapeutic purpose. These medicinal herbs should be tested in further combinations to determine their medicinal potentials. Miswak's therapeutic efficacy can be increased in many folds in combination with other medicinal herbs hence it should be further investigated. More research work should be conducted in the field of phytochemistry focusing on both in vitro and in vivo analyses and the isolation of bioactive compounds of interest [42].

\section{Conclusion}

In light of this study it can be concluded that herbs Kalonji, Miswak and Aloe vera were demonstrated to contain significant level of antimicrobial, anti-proliferative and antioxidant agents in them. It has been proved in this study that when two different herbs are used to evaluate antimicrobial activity the component of one herb dramatically changed the activity of other herb. The results of our study also revealed this intra-component activity of herb to herb combination (Kalonji and Aloe vera) when used alone against $S$. aureus showed ineffective result but a synergistic effect on antibacterial activity of these herbs has been observed when used in combination with Miswak in the same solvent. The optimum activity of herb was achieved when extracted in petroleum ether.

\section{Abbreviations}

EA: Ethanol Aloe vera; EK: Ethanol Kalonii; EM: Ethanol Miswak; PA: Petroleum ether Aloe vera; PK: Petroleum ether Kalonji; PM: Petroleum ether miswak; WA: Water Aloe Vera; WK: Water Kalonji; WM: Water Miswak

\section{Acknowledgements}

We are thankful to Mr. Muhamad Shoaib (Herbalist) to identify our herb samples used in this study.

\section{Funding}

This research did not receive any specific grant from funding agencies in the public, commercial, or not-for-profit sectors.

\section{Availability of data and materials}

The datasets used and/or analyzed during the current study available from the corresponding author on reasonable request.

\section{Authors' contributions}

SA, FA originally designed this study, TA and WM helped in sampling, SA, J, $K T$, MS, NM were involved in lab work, SA, KJ, SJA and FA did data analysis and drafted this manuscript. All authors read and approved the final manuscript.

\section{Competing interests}

All authors declared that they have no competing interest.

\section{Consent for publication}

Not applicable.

\section{Ethics approval and consent to participate}

Technical review committee of IMBB department, The University of Lahore gave approval for this study. No human sample was used in this study.

\section{Publisher's Note}

Springer Nature remains neutral with regard to jurisdictional claims in published maps and institutional affiliations.

\section{Author details}

Institute of Molecular Biology and Biotechnology (IMBB), The University of Lahore, Lahore, Pakistan. ${ }^{2}$ Department of University Institute of Medical Laboratory Technology, The University of Lahore, $1 \mathrm{~km}$ Defence Road off Raiwind road Lahore, Lahore, Pakistan. ${ }^{3}$ Fatima Memorial College of Medicine and Dentistry Lahore, Lahore, Pakistan.

Received: 24 November 2016 Accepted: 8 May 2017

Published online: 15 May 2017

\section{References}

1. Nunn JF. Ancient egyptian medicine: University of Oklahoma Press; 2002.

2. Costa E, Silva S, Tavaria F, Pintado M. Antimicrobial and antibiofilm activity of chitosan on the oral pathogen Candida albicans. Pathogens. 2014;3(4):908-19.

3. Bafti LS, Rad M, Soormaghi MS, Rezaei M. An in vivo evaluation of antimicrobial effects of Persica herbal mouthwash on Candida albicans and Enterococcus faecalis. Journal of Oral Health and Oral Epidemiology. 2013;2(2):64-9.

4. Noumi E, Snoussi M, Hajlaoui H, Valentin E, Bakhrouf A. Antifungal properties of Salvadora persica and Juglans regia L. extracts against oral Candida strains. Eur J Clin Microbiol Infect Dis. 2010;29(1):81-8.

5. Al-Daihan S, Al-Faham M, Al-shawi N, Almayman R. Brnawi A, shafi Bhat R: Antibacterial activity and phytochemical screening of some medicinal plants commonly used in Saudi Arabia against selected pathogenic microorganisms. Journal of King Saud University-Science. 2013;25(2):115-20.

6. Saad B, Said O. Greco-Arab and Islamic herbal medicine: traditional system, ethics, safety, efficacy, and regulatory issues: John Wiley \& Sons; 2011.

7. Mohamed SA, Khan JA. Antioxidant capacity of chewing stick miswak Salvadora persica. BMC Complement Altern Med. 2013;13(1):40.

8. Bhat PK, Kumar A, Sarkar S. Assessment of immediate antimicrobial effect of miswak extract and toothbrush on cariogenic bacteria-a clinical study. Journal of Advanced Oral Research. 2012;3(1):25-9.

9. Sajjad A, Subhani Sajjad S. Aloe vera: An ancient herb for modern dentistry - A literature review. Journal of Dental Surgery. 2014;2014

10. Fani M, Kohanteb J. Inhibitory activity of Aloe vera gel on some clinically isolated cariogenic and periodontopathic bacteria. J Oral Sci. 2012:54(1):15-21.

11. Davis RH, Donato J, Hartman GM, Haas RC. Anti-inflammatory and wound healing activity of a growth substance in Aloe vera. J Am Podiatr Med Assoc. 1994;84(2):77.

12. Nawahwi MZ, Ab Malek H. Antimicrobial activity of Nigella sativa seed extract. Sains Malaysiana. 2013;42(2):143-7.

13. Kokoska L, Havlik J, Valterova I, Sovova H, Sajfrtova M, Jankovska I. Comparison of chemical composition and antibacterial activity of Nigella sativa seed essential oils obtained by different extraction methods. J Food Prot. 2008;71(12):2475-80.

14. Khan M, Ashfaq M, Zuberi H, Mahmood M, Gilani A. The in vivo antifungal activity of the aqueous extract from Nigella sativa seeds. Phytother Res. 2003;17(2):183-6.

15. Dzoyem JP, Aro AO, McGaw LJ, Eloff JN. Antimycobacterial activity against different pathogens and selectivity index of fourteen medicinal plants used in southern Africa to treat tuberculosis and respiratory ailments. S Afr J Bot. 2016:102:70-4.

16. Che C-T, Wang ZJ, Chow MSS, Lam CWK. Herb-herb combination for therapeutic enhancement and advancement: theory, practice and future perspectives. Molecules. 2013;18(5):5125-41.

17. Bag A, Chattopadhyay RR. Evaluation of synergistic antibacterial and antioxidant efficacy of essential oils of spices and herbs in combination. PLoS One. 2015;10(7):e0131321.

18. Togan T, Evren $\mathrm{E}$, Ciftci $\mathrm{O}$, Narci $\mathrm{H}$, Ozcan MM, Arslan $\mathrm{H}$. The antibacterial effect of Propolis against clinical isolates. Blood. 2015;7(7):30.

19. Handa SS, Khanuja SPS, Longo G, Rakesh DD. Extraction technologies for medicinal and aromatic plants United nations industrial development organisation and the international centre for science and high technology. International Centre for Science and High Technology- United Nations Industrial Development Organization, area Science Park Padriciano. 2008;99:34012.

20. Raval BP, Shah TG, Patel JD, Patel BA, Patel RK, Suthar MP. Potent anticancer activity of Nigella sativa seeds. Arch Appl Sci Res. 2010;2(1):52-6.

21. Shamim S, Rehman A. Antioxidative enzyme profiling and biosorption ability of Cupriavidus metallidurans $\mathrm{CH} 34$ and Pseudomonas putida $\mathrm{mt} 2$ under cadmium stress. J Basic Microbiol. 2015;55(3):374-81. 
22. Darout IA, Skaug N, Albandar JM. Subgingival microbiota levels and their associations with periodontal status at the sampled sites in an adult Sudanese population using miswak or toothbrush regularly. Acta Odontol Scand. 2003;61(2):115-22.

23. Vahabi S, Najafi E, Alizadeh S. In vitro antimicrobial effects of some herbal essences against oral pathogens. Journal of Medicinal Plants Research. 2011;5(19):4870-8

24. Rath S, Padhy RN. Antibacterial efficacy of five medicinal plants against multidrug-resistant enteropathogenic bacteria infecting under-5 hospitalized children. Journal of Integrative Medicine. 2015;13(1):45-57.

25. Xu KD, McFeters GA, Stewart PS. Biofilm resistance to antimicrobial agents. Microbiology. 2000;146(3):547-9.

26. Archer NK, Mazaitis MJ, Costerton JW, Leid JG, Powers ME, Shirtliff ME. Staphylococcus aureus biofilms: properties, regulation, and roles in human disease. Virulence. 2011;2(5):445-59.

27. Al-Bayati FA, Sulaiman KD. In vitro antimicrobial activity of Salvadora persica L. extracts against some isolated oral pathogens in Iraq. Turk J Biol. 2008;32(1):57-62.

28. Al-Obaida MI, Al-Essa MA, Asiri AA, Al-Rahla AA. Effectiveness of a $20 \%$ Miswak extract against a mixture of Candida albicans and Enterococcus faecalis. Saudi Med J. 2010;31(6):640-3.

29. Salehi P, Sh MD. Comparison of the antibacterial effects of persica mouthw ash with chlorhexidine on streptococcus mutans in orthodontic patients. DARU Journal of Pharmaceutical Sciences. 2006;14(4):178-82.

30. El-Latif Hesham A, Alrumman SA. Antibacterial activity of Miswak (Salvadora persica) extracts against isolated and genetically identified oral cavity pathogens. Technol Health Care. 2016;24:S841-S84.

31. Omer AG, Qarani SM, Khalil AK. In vitro antimicrobial activity of Miswak extracts against some oral pathogenic isolates. Zanco Journal of Medical Sciences. 2010;14(1):71-8.

32. Teka A, Rondevaldova J, Asfaw Z, Demissew S, Van Damme P, Kokoska L, Vanhove W. In vitro antimicrobial activity of plants used in traditional medicine in Gurage and Silti Zones, south central Ethiopia. BMC Complement Altern Med. 2015;15(1):286.

33. Bakathir HA, Abbas NA. Detection of the antibacterial effect of Nigella sativa ground seeds with water. Afr J Tradit Complement Altern Med. 2011;8(2):159-64.

34. Khan AU, Ali S, Rehman AU, Ali H, Ahmad T, Waqar M, Niaz Z. Antibacterial Activity of Nigella sativa and Piper nigrum. Asian Journal of Natural and Applied Sciences. 2013;2(4):173-9.

35. Villalobos OJ, Salazar V, Rosa C. Ramirez de Sanchez G: Efecto de un enjuague bucal compuesto de Aloe vera en la placa bacteriana e inflamacion gingival. Acta Odontol Venez. 2001;39(2):16-24

36. SMAd O, Torres TC, SLdS P, OMdL M, Carlos MX. Effect of a dentifrice containing Aloe vera on plaque and gingivitis control: A double-blind clinical study in humans. J Appl Oral Sci. 2008;16(4):293-6.

37. Coopoosamy R, Magwa M: Traditional use, antibacterial activity and antifungal activity of crude extract of Aloe excelsa. Afr J Biotechnol. 2007; 6(20):2406-2410.

38. Ahmad A, Husain A, Mujeeb M, Khan SA, Najmi AK, Siddique NA, Damanhouri ZA, Anwar F. A review on therapeutic potential of Nigella sativa: A miracle herb. Asian Pacific Journal of Tropical Biomedicine. 2013;3(5):337-52.

39. Jackson C, Agboke A, Nwoke V. In vitro evaluation of antimicrobial activity of combinations of nystatin and Euphorbia hirta leaf extract against Candida albicans by the checkerboard method. Journal of Medicinal Plants Research. 2009;3(9):666-9.

40. Odhiambo JA, Siboe GM, Lukhoba CW, Dossaji SF. Antifungal activity of crude extracts of selected medicinal plants used in combinations in Lake Victoria Basin, Kenya. Plant Product Research Journal. 2009;13:35-43.

41. Zhou X, Seto SW, Chang D, Kiat H, Razmovski-Naumovski V, Chan K, Bensoussan A. Synergistic effects of Chinese herbal medicine: a comprehensive review of methodology and current research. Front Pharmacol. 2016;7

42. Chan EWC, Wong SK. Phytochemistry and pharmacology of ornamental gingers, Hedychium coronarium and Alpinia purpurata: a review. Journal of Integrative Medicine. 2015;13(6):368-79.

\section{Submit your next manuscript to BioMed Central and we will help you at every step:}

- We accept pre-submission inquiries

- Our selector tool helps you to find the most relevant journal

- We provide round the clock customer support

- Convenient online submission

- Thorough peer review

- Inclusion in PubMed and all major indexing services

- Maximum visibility for your research

Submit your manuscript at www.biomedcentral.com/submit
Biomed Central 